\title{
Performance Analysis of Fuzzy Logic-based Controller for MPPT of PV Cell

\author{
${ }^{1}$ Chandragiri Radhacharan, ${ }^{\square} 2$ Toom Nithin Chandra \\ ${ }^{1,2}$ Department of Electrical and Electronics Engineering, JNTUH College of Engineering, Nachupally, Jagtial, \\ Telangana \\ crc190882@gmail.com,nithinc506@gmail.com
}

Received: 18th July 2020, Accepted: 27th July 2020, Published: 31st August 2020

\begin{abstract}
This paper presents the design of the fuzzy logic controller for maximum power point tracking (MPPT) of a PV cell. Output power of the PV cell is a function of solar irradiation, operating temperature and also depend on impedance seen by it. When there a change in any above parameters the power output of the PV cell goes apart from the maximum power point. so, there should be an algorithm which able to maintain output power at maximum power point. This paper uses a fuzzy logic-based algorithm for maximum power point tracking (MPPT). A change in irradiation level is provided to PV cell and the simulation results show it able to track the maximum power point and improve the dynamic response of the system. All Simulations are done in MATLAB 2020a software.
\end{abstract}

Keywords

MPPT, Photovoltaic, Boost Converter, Membership Functions, Fuzzy Logic.

\section{Introduction}

In recent years there is a positive trend for the generation of electric energy through renewable sources, as the demand graph is exponentially rising. There is an urge for the energy generation to cope up the sustainable demand as the constraints like global warming and limited fossil fuel resources block the option of the generation of energy in large scale through conventional sources [1].

Among all the renewable energy sources, solar energy is such a prominent choice, as one can supply all-day power with the help of advance technologies in rising efficiency of batteries where it can be considered for that exponential rise in load demand as an alternative to fossil fuels [2].

But due to low efficiency in energy conversion of the PV cell, there is a necessity to run the PV cell at the maximum power point. which is a point on output power and voltage curve of the PV cell. This curve is drawn for specific irradiation and temperature. So, there are different MPP curves for a different combination of irradiation and temperature. the goal of these algorithms is to maintain operating point at maximum power point of that particular curve despite variations in solar irradiance and operating temperature.

A.Various Methods for MPPT

Many algorithms are proposed for tracking maximum power point most commonly employed methods are based on the reference cell method (sorted to voltage or current scaling), power slope method, hill-climbing method. The popular algorithms like $\mathrm{P} \& \mathrm{O}$ are based on a hill-climbing method where a perturb in voltage given and power variation is observed to obtain peak power point but there are large oscillations in output. Incremental conductance method is complicated and not preferable for rapid changes in solar irradiation and temperature [3,4]. Where soft computing-based algorithms like fuzzy logic, neural networks are faster in response with high stability. And the fuzzy controller is based on power slope method. This paper talks about how to design and model the fuzzy logic controller to track the maximum power point of the PV cell. Fuzzy logic is a multi-valued logic, unlike Boolean logic which is bivalent logic i.e., 0 and 1. Fuzzy logic uses a linguistic-based approach to deal with a problem. This algorithm is performed on a PV cell which is modelled using mathematical equations in MATLAB Simulink. Design and Modelling

A typical MPPT based PV system has a PV array, controller, DC-DC converter. Figure 1. Shows the block diagram of fuzzy logic based MPPT controller for PV system

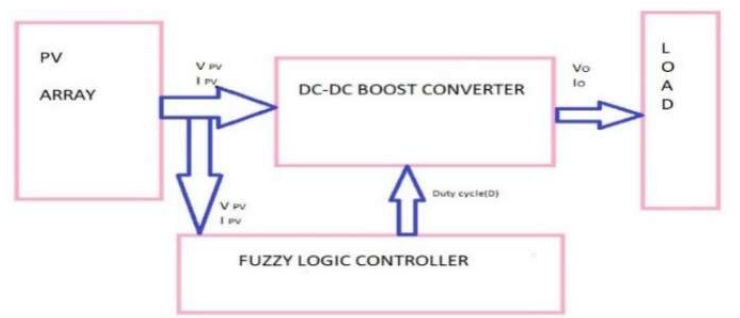

Fig. 1: Block Diagram of PV System 
A.Mathematical Modeling of PV Cell

$\mathrm{PV}$ cell can be modelled as an electrical equivalent circuit consisting of two resistors. Series resistance is accounted for losses due to material resistance at metal contacts in a metal grid and shunt resistance is accounted for the leakage current i.e., non-ideality of the diode.

The output current of the PV cell $: I=I_{p h}-I_{0}\left[\exp \left(\frac{q\left(V+I R_{S}\right)}{n N_{s} k T}\right)-1\right]-I s h$

The current generated due to irradiation i.e., photocurrent: $I_{P h}=\left[I_{s c}+K_{i}(T-298)\right] \frac{G}{G \text { ref }}$

Saturation current: $I_{0}=I_{R S}\left(\frac{T}{T_{n}}\right)^{3} \exp \left[\frac{q E_{g 0}\left(\frac{1}{T_{n}}-\frac{1}{T}\right)}{n k}\right]$

Current through shunt resistor: $I_{s h}=\left(\frac{V+I R_{S}}{R_{S h}}\right)$

Reverse saturation current: $I_{R s}=I_{s c} /\left(\left(e^{\wedge}\left(\frac{q V_{o c}}{n N s . k T}\right)\right)-1\right)$

where, $\mathrm{V}=$ output voltage of $\mathrm{PV}$ cell, $\mathrm{R}_{\mathrm{s}}=$ series resistance, $\mathrm{R}_{\mathrm{sh}}=$ shunt resistance, $\mathrm{I}_{\mathrm{sc}}=$ short circuit current of $\mathrm{PV}$ cell,

$\mathrm{K}_{\mathrm{i}}=$ cells short circuit current temperature coefficient, $\mathrm{T}=$ operating temperature $(\mathrm{K}), \mathrm{n}=$ the ideality factor of the diode, $\mathrm{N}_{\mathrm{s}}=$ no of cells connected in series, $\mathrm{q}=$ electron charge, $\mathrm{E}_{\mathrm{g} 0}=$ bandgap energy of the semiconductor, $\mathrm{T}_{\mathrm{n}}=$ nominal temperature $(\mathrm{K}), \mathrm{G}=$ solar irradiation, $\mathrm{k}=$ Boltzmann's constant, $\mathrm{V}_{\mathrm{oc}}=$ open circuit voltage.

Above mathematical equations are modelled in MATLAB Simulink shown in figure 2. (a) and a controlled current source is attached to the PV module as in figure 2(b). So total combination behaves as a PV cell [5].

Module is designed to output a maximum power of $70 \mathrm{~W}$ at $1000\left(\mathrm{~W} / \mathrm{m}^{2}\right)$ and $25\left({ }^{\circ} \mathrm{C}\right) \mathrm{PV}$ curve of the cell shown in figure.3, parameters set as, $\mathrm{R}_{\mathrm{s}}=0.016 \Omega, \mathrm{K}_{\mathrm{i}}=0.0032, \mathrm{k}=1.38 \mathrm{e}-23(\mathrm{~J} / \mathrm{K}), \mathrm{n}=2, \mathrm{E}_{\mathrm{g} 0}=1.16 \mathrm{eV}, \mathrm{R}_{\mathrm{sh}}=500 \Omega, \mathrm{G}_{\mathrm{ref}}=$ $1000\left(\mathrm{~W} / \mathrm{m}^{2}\right)$. Electrical parameters are shown in table 1.
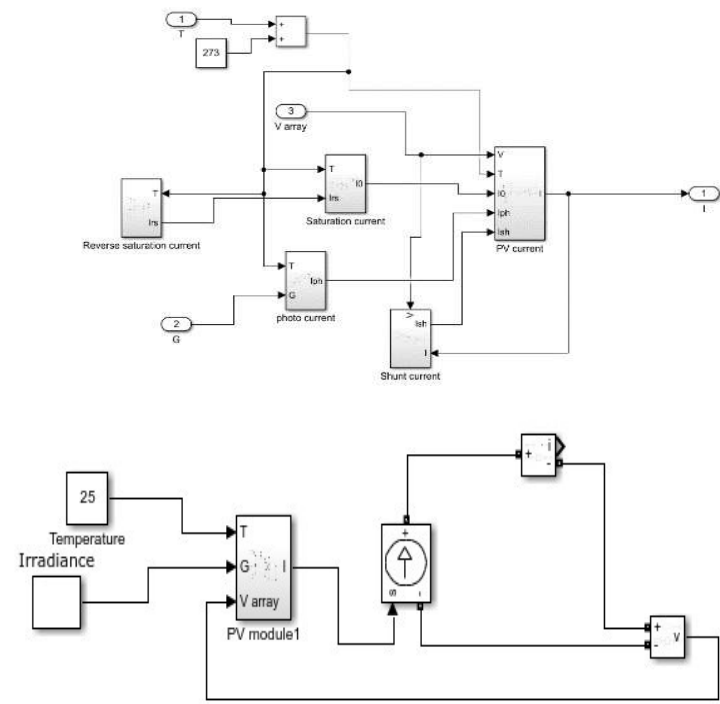

(a)

(b)

Fig. 2: (a) Internal Block of PV Module in Simulink. (b) Module Connected to a Controlled Current Source Act as PV Cell

Table 1: Electrical Parameters of the PV Cell for various Irradiation Levels

\begin{tabular}{|c|l|l|}
\hline Parameter & $\begin{array}{c}\text { Specifications at } \mathbf{G}=\mathbf{1 0 0 0} \\
\left(\mathbf{w} / \mathbf{m}^{\mathbf{2}}\right) \text { and } \mathbf{T}=\mathbf{2 5}\left({ }^{\circ} \mathrm{C}\right)\end{array}$ & $\begin{array}{c}\text { Specifications at } \mathbf{G}=\mathbf{7 0 0} \\
\left(\mathbf{w} / \mathbf{m}^{2}\right) \text { and } \mathbf{T}=\mathbf{2 5}\left({ }^{\circ} \mathrm{C}\right)\end{array}$ \\
\hline Short circuit current $\left(\mathbf{I}_{\mathbf{s c}}\right)$ & $4 \mathrm{~A}$ & $2.8 \mathrm{~A}$ \\
\hline Open circuit voltage $\left(\mathbf{V}_{\mathbf{o c}}\right)$ & $25 \mathrm{~V}$ & $24.3 \mathrm{~V}$ \\
\hline Voltage at max power $\left(\mathbf{V}_{\mathbf{m p}}\right)$ & $19.55 \mathrm{~V}$ & $19.01 \mathrm{~V}$ \\
\hline Current at max power $\left(\mathbf{I}_{\mathbf{m p}}\right)$ & $3.58 \mathrm{~A}$ & $2.55 \mathrm{~A}$ \\
\hline Rated power & $70 \mathrm{~W}$ & $48.5 \mathrm{~W}$ \\
\hline No of cells in series $\left(\mathbf{N}_{\mathbf{s}}\right)$ & 40 & 40 \\
\hline No of cells in parallel & 1 & 1 \\
\hline
\end{tabular}




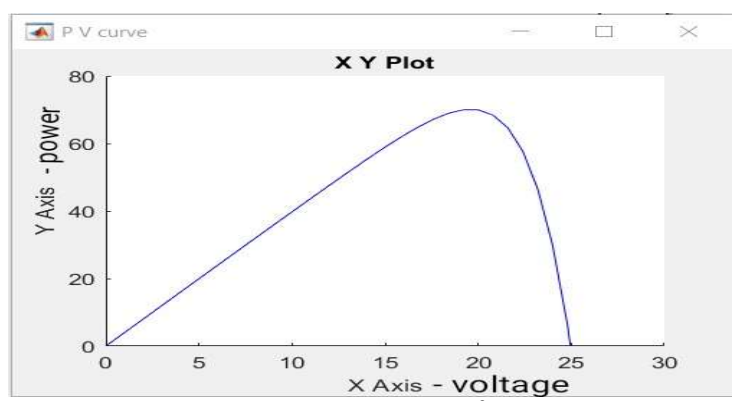

Fig. 3: PV Curve at Irradiation $1000\left(\mathrm{~W} / \mathrm{m}^{2}\right)$ and Temperature $25\left({ }^{\circ} \mathrm{C}\right)$

\section{B. Design of DC-DC Boost Converter}

A DC-DC Boost converter step up the input voltage given to it with negligible power loss so it can be understood that input power is equal as output power and figure 4 . Shows the circuit diagram of boost converter it consists of a switch (MOSFET), input and output capacitor, an inductor.

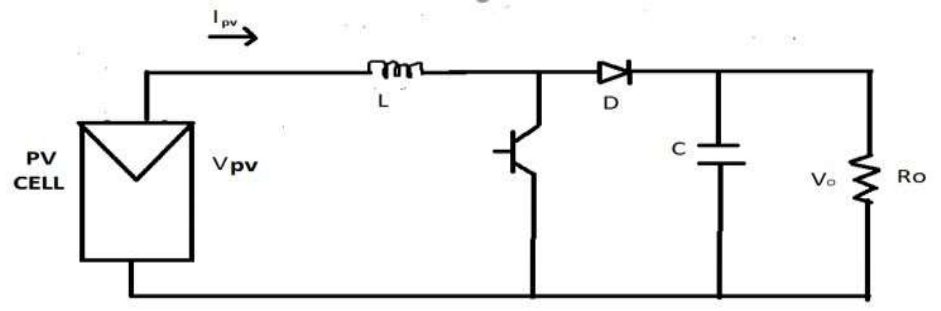

Fig. 4: Boost Converter Block Diagram

when the switch is on the voltage across the inductor is $\mathrm{V}_{\mathrm{pv}}$, and switch is off it is $\left(\mathrm{V}_{\mathrm{o}}-\mathrm{V}_{\mathrm{pv}}\right)$. So, the voltagesecond balance equation across the inductor is $V p v \cdot D T+\left(V p v-V_{0}\right) \cdot(1-D) T=0$

When the switch is on capacitor act as source and delivers current to load. So, the current through it is $\left(-\mathrm{I}_{\mathrm{o}}\right)$ and switch is off the current through it is $\left(I_{\mathrm{pv}}-\mathrm{I}_{0}\right)$ so ampere-second balance equation is $\left(-I_{0}\right) \cdot D T+$ $\left(I p v-I_{0}\right)(1-D) T=0$

Thus, Voltage across load: $V_{0}=V p v\left(\frac{1}{1-D}\right)$

Current through load: $I_{0}=\operatorname{Ipv}(1-D)$

So, output resistance $\left(\mathrm{R}_{\mathrm{o}}\right)$ is given by dividing load voltage by load current $R_{0}=\frac{V p v}{I p v}\left(\frac{1}{(1-D)^{2}}\right)$

Input resistance( $\mathrm{R})$ is input voltage by input current so $R=R_{0}(1-D)^{2}$

Where $\mathrm{D}=$ duty cycle $=$ Ton $/ \mathrm{T}$.

The input resistance of DC-DC Boost converter i.e., Impedance seen by PV cell is a function of the duty cycle. The operating point of the PV cell depends upon impedance seen by the PV cell. If there is a change in irradiation and temperature operating point changes. So, the controller should decide the duty cycle to make out the change such that the operating point is at peak power point [6]. Parameters of Boost converter are shown in table 2.

Table 2: Boost Converter Parameters

\section{Fuzzy Logic Controller}

\begin{tabular}{|l|l|}
\hline Inductance(L) & $0.471 \mathrm{mH}$ \\
\hline Input capacitance $\left(\mathbf{C}_{\text {in }}\right)$ & $800 \mu \mathrm{F}$ \\
\hline Output capacitance $\left(\mathbf{C}_{\text {out }}\right)$ & $60 \mu \mathrm{F}$ \\
\hline Frequency & $25 \mathrm{kHz}$ \\
\hline
\end{tabular}

Fuzzy logic controllers are becoming popular these days due to ease of design and able to handle the nonlinear control with help of indefinite inputs. A fuzzy controller block diagram is shown in figure 5.Consists of 3 main sub-blocks fuzzification block, fuzzy inference block, De-fuzzification block [7].

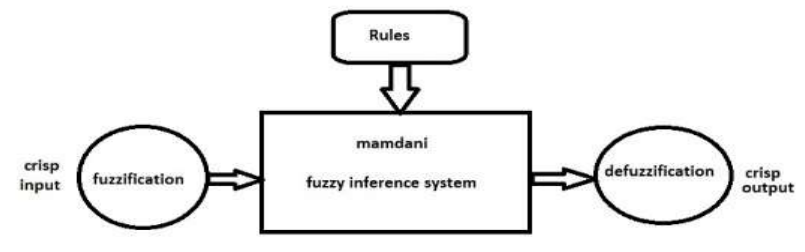

Fig. 5: Block Diagram of Fuzzy Controller 
Fuzzification block takes crisp input gives out fuzzy value by the help of membership functions mainly triangular, trapezoidal, Gaussian. Then fuzzified inputs are sent to fuzzy inference block where there are certain setup rules which are based on the linguistic way in form of If-Then, mainly two types of inference engines, Mamdani and Takagi-Sugeno [8].

De-fuzzification is a process where the fuzzy values are transformed into crisp outputs. Many types include adaptive integration, Bisector of area, centroid, fuzzy mean etc.

Input 1 i.e., error and input 2 i.e., change in error shown in figure 6 and figure 7 are given to fuzzification block where it uses triangular membership functions to convert crisp input into fuzzy values and in which rules are defined based on Mamdani fuzzy inference system are shown in figure 8 and centroid defuzzification used for obtaining crisp output.

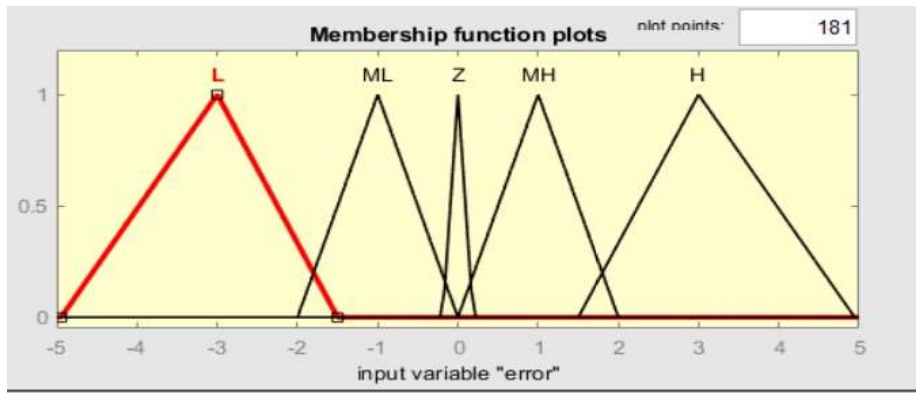

Fig. 6: Input 1 Membership Function

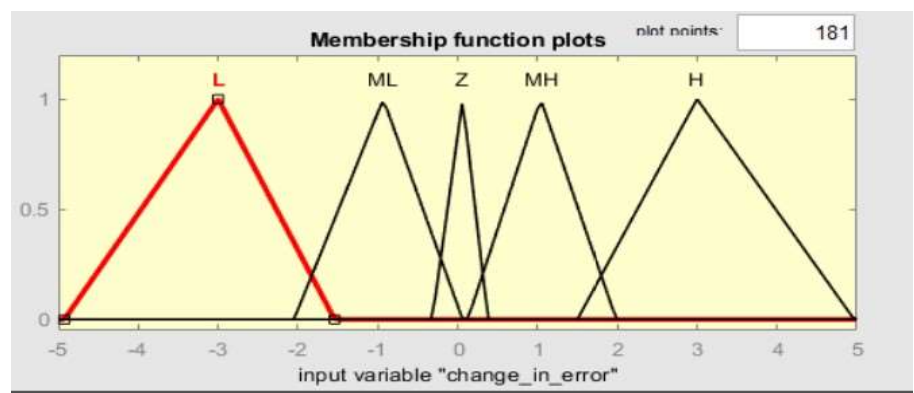

Fig. 7: Input 2 Membership Function

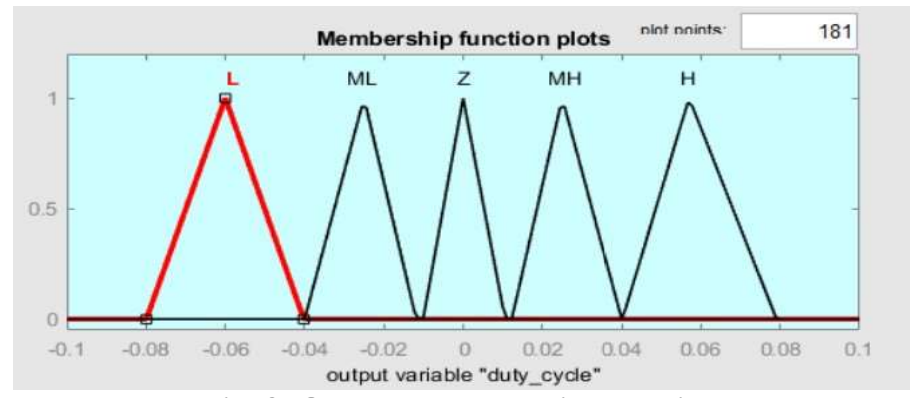

Fig. 8: Output Membership Function

Output i.e., change in duty cycle is decided by passing out inputs error and change in error through fuzzy controller block.

Input1, error i.e., change in voltage $\Delta \mathrm{V}$ which is the difference between previous voltage and present. It defines how far is the current operating point from MPP and Input2, change in error, which is the difference between previous power to present power expressed in a fraction of change in voltage, nothing but the slope of PV curve $\frac{\Delta \mathrm{P}}{\Delta \mathrm{V}}$. It defines where the operating point lie left or right side of the peak power point and output change in duty cycle $\triangle$ Dis decided and the duty cycle is corrected with the change until peak power point is obtained Duty cycle is given by

$$
D(t)=\triangle D(t-1)+\triangle D(t)
$$

The modelled fuzzy controller in Simulink is shown in figure 9.

Where, $\Delta V=V(t)-V(t-1)$

$\Delta P=\Delta P(t)-\Delta P(t-1)$

5 levels of membership functions are used low(L), medium-low (ML), zero(Z), medium-high $(\mathrm{MH})$, high $(\mathrm{H})$ shown in table 3. 
Table 3: Fuzzy Rule Matrix

\begin{tabular}{|c|l|l|l|l|l|}
\hline $\mathbf{E} / \mathbf{C E}$ & \multicolumn{1}{|c|}{$\mathbf{L}$} & \multicolumn{1}{|c|}{ ML } & \multicolumn{1}{c|}{ MH } & \multicolumn{1}{c|}{ H } \\
\hline $\mathbf{L}$ & MH & H & L & L & ML \\
\hline ML & MH & MH & ML & ML & ML \\
\hline $\mathbf{Z}$ & Z & Z & Z & Z & Z \\
\hline MH & ML & ML & MH & MH & MH \\
\hline H & ML & L & H & H & MH \\
\hline
\end{tabular}

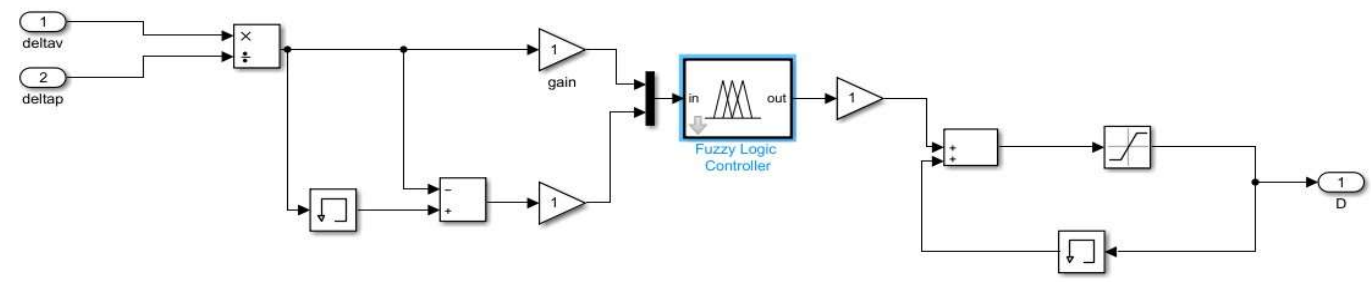

Fig. 9: Fuzzy Controller Modelled in Simulink

\section{Results and Discussion}

Modelled fuzzy MPPT system shown in figure 10. Contain $70 \mathrm{~W}$ PV panel and DC-DC Boost converter with the inductance of $0.471 \mathrm{mH}$ and input capacitance of $60 \mu \mathrm{F}$ and output capacitance of $800 \mu \mathrm{F}$ and the switching frequency of $25 \mathrm{kHz}$.

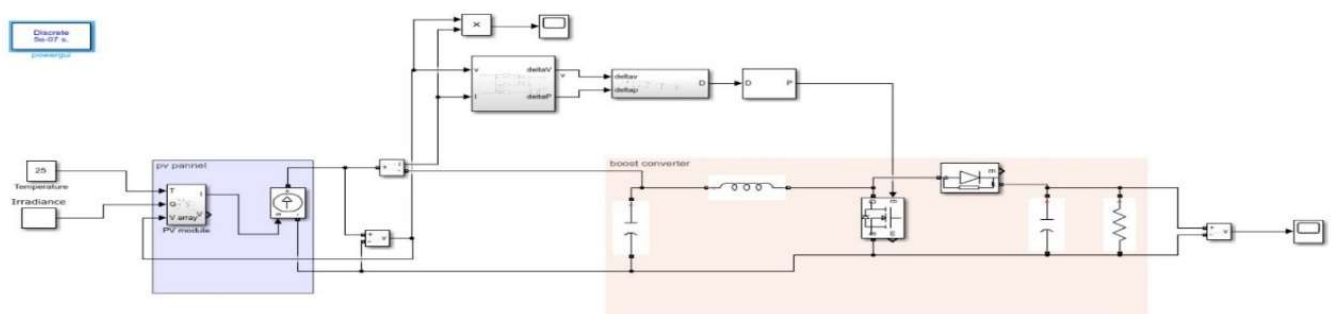

Fig. 10: PV MPPT System Modelled in Simulink

Two types of tests are conducted i.e., sudden rise and fall of irradiation.

Test 1 . The irradiation is kept $1000\left(\mathrm{~W} / \mathrm{m}^{2}\right)$ and at $10(\mathrm{~ms})$ the irradiation is changed to $700\left(\mathrm{~W} / \mathrm{m}^{2}\right)(\mathrm{drop}$-in irradiation).

Test 2. The irradiation is kept $700\left(\mathrm{~W} / \mathrm{m}^{2}\right)$ and at $10(\mathrm{~ms})$ the irradiation is changed to $1000\left(\mathrm{~W} / \mathrm{m}^{2}\right)($ rise in irradiation).

where the output voltage of the PV cell is shown in figure 11. The output power for test 1 is shown in figure 12 . and test 2 in figure 13. Make out that controller able to track MPP more accurately with a variation of $1.5 \mathrm{~W}$ and within 0.01 second.

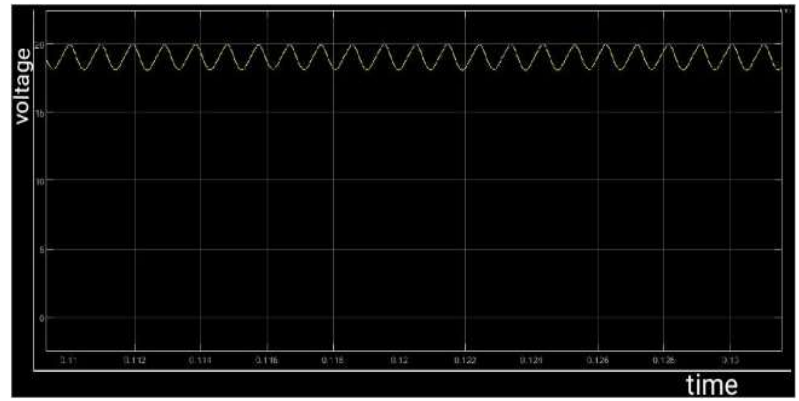

Fig. 11: PV Cell Output Voltage at Irradiation of $1000\left(\mathrm{~W} / \mathrm{m}^{2}\right)$ at $25\left({ }^{\circ} \mathrm{C}\right)$ 


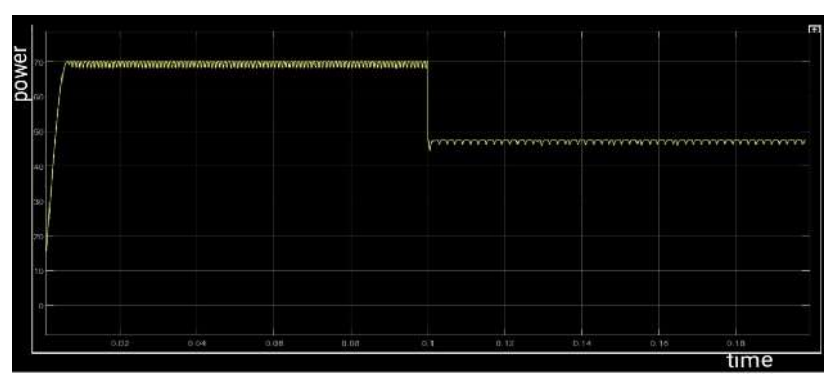

Fig. 12: Power Output for Test 1 where the Irradiation Dropped from 1000 to $700\left(\mathrm{~W} / \mathrm{m}^{2}\right)$ at 0.1 (S)

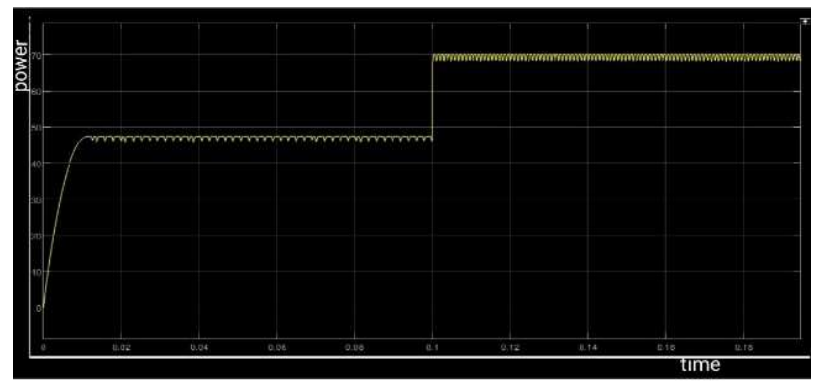

Fig. 13: Power Output for Test 2 where the Irradiation Raised from 700 to $1000\left(\mathrm{~W} / \mathrm{m}^{2}\right)$ at $0.1(\mathrm{~S})$ The performance under various atmospheric conditions by varying both irradiation and temperature at 0.02 second intervals with $1000 \mathrm{~W} / \mathrm{m}^{2}, 700 \mathrm{~W} / \mathrm{m}^{2}, 500 \mathrm{~W} / \mathrm{m}^{2}$ and $25^{\circ} \mathrm{C}, 30^{\circ} \mathrm{C}, 35^{\circ} \mathrm{C}$ is shown in fig. 14 .

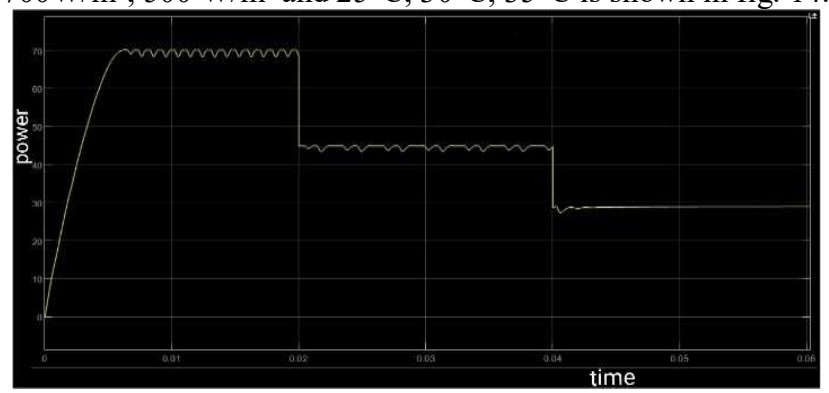

Fig. 14: Power Output for Changes in Irradiation and Temperature.

\section{Conclusion}

In this paper fuzzy logic controller based MPPT tracking mechanism is performed on $70 \mathrm{~W}$ panel and components of the PV system are modelled in MATLAB 2020a using Simulink. The system is tested with different test signals with variable irradiation under constant temperature. It is observed that the controller can track maximum power point with an average power output of $68.5 \mathrm{Wwith}$ an accuracy of $97.8 \%$ and after a drop in irradiation with an average power output of $48 \mathrm{~W}$ with an accuracy of $98.96 \%$ and low oscillations around the maximum power point. Further, performance is evaluated around various atmospheric conditions, show that the controller was able to track maximum power point more effectively than conventional methods.

\section{References}

[1] Gielen D, Boshell F, Saygin D, Bazilian MD, Wagner N, Gorini R, "The role of renewable energy in the global energy transformation,” Energy Strategy Reviews, Vol 24, April 2019. https://www.mendeley.com/catalogue/8dadc69d-6e90-366a-ad84-aa231b64060e/

[2] Mohd R S, Santosh B W, Suvarna S L, Pooja V F, Anil T, "A Review Paper on Electricity Generation from Solar Energy," International Journal for Research in Applied Science and Engineering Technology, Vol 5, Issue 9, Sept 2017. http://ijraset.com/fileserve.php?FID=10230

[3] Elzalik M, Mustafa F, Mostafa R. "Study of Maximum Power Point Tracking (MPPT) In PV Systems," International Journal of Research in Engineering and Advanced Technology,Vol4, Issue 5, Oct-Nov, 2016.http://www.ijreat.org/Papers\%202016/Issue23/IJREATV4I5005.pdf

[4] William C, Ramesh R, "comparative study of P\&O and Inc MPPT Algorithms," American Journal of Engineering Research, vol 2, Issue 12,2013.http://www.ajer.org/papers/v2(12)/ZT212402408.pdf

[5] El-Basit WA, El AMA, "Mathematical Model for Photovoltaic Cells," Leonardo Journal of Sciences, Issue 23, July-December 2013. http://ljs.academicdirect.org/A23/013 028.pdf 
[6] Motahhir S, El Ghzizal A, Sebti S, Derouich A, "Modeling of Photovoltaic System with Modified Incremental Conductance Algorithm for Fast Changes of Irradiance," International Journal of Photoenergy, Mar 2018. https://www.hindawi.com/journals/ijp/2018/3286479/

[7]Gerla G, "Fuzzy Logic Programming and Fuzzy Control," Studia Logica 79, Mar 2005.https://link.springer.com/article/10.1007/s11225-005-2977-0

[8] Izquierdo, Segismundo S. and Izquierdo, Luis R. "Mamdani Fuzzy Systems for Modelling and Simulation: A Critical Assessment," Journal of Artificial Societies and Social Simulation 21 (3) $2,2018$. http://jasss.soc.surrey.ac.uk/21/3/2.html 